\title{
Research and Trends in Technology and Gifted Child: Results of a Content Analysis
}

https://doi.org/10.3991/ijet.v14i22.11751

\author{
Huseyin Uzunboylu $\left({ }^{\varpi}\right)$ \\ Near East University, Mersin 10, Turkey \\ huseyin.uzunboylu@gmail.com
}

Zehra Ozcinar

Ataturk Teacher Training Academy, Mersin 10, Turkey

Sergey M. Kolotushkin

Federal Penal Administration Service Research Institute, Moscow, Russia

Olga A. Kalugina

Financial University under the Government of the Russian Federation, Moscow, Russia

Teymur E. Zulfugarzade

Plekhanov Russian University of Economics, Moscow, Russia

\begin{abstract}
The purpose of this study was to examine research and trends in technology usage in gifted child published in selected professional sources during the period 1990-2019. Content and Citation analysis was used in this study to investigate documents related to technology usage in gifted child researches, which were indexed in the Web of Science. "Technology" and "gifted" (high abilities) related keywords were used jointly in the search for documents. There was a total of 240 documents judged to be relevant to the field of technology usage in gifted child education and were analyzed. However, as a result of individual review of the sources, 40 documents that were not relevant for the purpose of the research were excluded from the scope of the research. As a result of this study, it can be seen that the documents and the number of citations related to the technology usage in gifted child education field has been continuously increasing since 2005 . It is recommended that a combination of citation analysis and other types of analyses should be used in future research studies.
\end{abstract}

Keywords-Technology usage, gifted child, citation analysis, research, trends, h-index.

\section{Introduction}

Technological advances have expanded the limits of human knowledge. Technology has been used in the field of education (Umachandran, Corte, Amuthalakshmi, James, Said, Sawicka, Gaudio, Mohan, Refugio, Aravind, \& Jurcic, 2019; Yildiz, 
Alkan \& Cengel, 2019; Baglama, Haksiz \& Uzunboylu, 2018). The use of technology in the educational environment is increasing day by day. Educational technology helps achieve the intended objectives (Yilmaz, 2007). Computer-aided education, which has also been used in the education of individuals in need of special education, has produced positive results (Sancar, Tozkoparan, \& Odabasi, 2017; Kurt, \& Goksun, 2016; Keser, \& Erdem, 2019). Education, which responds to almost every person, is connected to life at every stage of life from birth to death for gifted students (Aruk, 2008). Gifted students maybe different from their peers with the characteristics of good learning, questioning, independent learning and focusing their attention on a particular subject for longer. Therefore, the curriculum to be applied to these individuals should be different, deep and long-lasting according to their characteristics and in a way meeting their educational needs (Hırça \& Bayrak, 2013; Sahmurov, Aylak, Bedirhanbeyoglu \& Gulen, 2017; Shubina, \& Kulakli, 2019). Technological research on gifted individuals is considered in the literature under the concept of assistive technology (Catak \& Tekinarslan, 2008). The concept of assistive technology in gifted education can be defined as all kinds of tools and materials, whether or not developed for commercial purposes, to increase, maintain or physically improve the functional abilities of gifted individuals (Brackenreed, 2008).

One of the most widely used assistive technologies from past to today is computers. Computer is an electronic tool that tabulates, stores and keeps electronic data (Umachandran, Corte, Amuthalakshmi, James, Said, Sawicka, Gaudio, Mohan, Refugio, Aravind and Jurcic, 2019). With the introduction of computer in the educational environment, it is believed that educators have the opportunity to develop richer materials in terms of visual and auditory by the help of various computer programs (Kayapinar and Savas, 2019). Supporting teaching with materials is one of the topics that educators have emphasized most in recent years (Kurtdede Fidan, 2008). The main purpose of supporting teaching with materials is to further improve effectiveness of teaching (Rotter, 2006). The use of tablet PCs as an educational material for gifted students is finding forms recently and studies on this subject are continuing. In order for tablet PCs to be used effectively in the education of gifted students, the educational software to be used must certainly be prepared and designed according to the characteristics of children (Wembler, 2010). Today, tools and materials emerging in parallel with technological developments are increasing rapidly in number and type each year and cover a wide area ranging from very simple to extremely complex structures. The most important feature of the education supported by the material is that it makes teaching more interesting, immersive, efficient and economical (Seferoğlu, 2006).

The number of gifted students in the world is increasing day by day. Today, this number is over 500 million (Yıldiz, 2010). In recent years, a new formation has started in the world of computer and Internet for many gifted students. Computers and ways of access to information have been redesigned with different opportunities for gifted students (Özgüç \& Cavkaytar, 2014). With the help of changes in computer technologies, students with special educational needs can communicate by telephone connection or read a computer screen through synthesis (Subaşığlu, 2008).

In the Marland Report published in 1972, characteristics of gifted and talented children were defined as gifted or talented child, a child performing very well thanks 
to his unusually gifted talents (Johnsen, 2012). These children demonstrate one or a combination of more abilities or characteristics: general mental ability, special academic ability, creative or productive thinking, leadership ability, visual and performance-based art ability, and psychometry ability. Early developmental characteristics of gifted and talented children include the unusual agility of the baby, careful examination of objects, early development of awareness of stimuli, length of attention span, and low need for sleep. (Umar \& Reis, 2013).

\subsection{Gifted child and technology}

In Turkey, Scientific and Technological Research Council of Turkey (TUBITAK), for the gifted students to come together with technology, aims to support young researchers and basic and applied academic research in the natural sciences and aims to encourage gifted individuals to research and to grow as future scientists. In this period, it is also seen that validity and reliability studies on the use of different intelligence tests in Turkey have began. Moreover, "Anadolu-Sak Intelligence Scale" is developed by Sak (2017) in Turkish and in accordance with Turkish culture.

In every school and every classroom, gifted and talented students' classrooms can be found. In these classes, individual characteristics and needs of students may be different. These students need a differentiated education in which their individual needs are overseen far beyond the education given in normal schools in order to be aware of themselves and contribute to both the society in which they live and to themselves. When we look at the literature, it can be said that the lack of studies about gifted students and technology is a major deficiency for those student. Further studies on gifted students and technology should be made in the literature in order to shed light on the better education of gifted students and to enable researchers to see clearly. This should be considered as a research need and reviews should be conducted to evaluate the relevant research.

\subsection{The purpose of study}

The purpose of this study is to examine researches and trends in technology usage in gifted child published in selected professional sources during the period 1990-2019. In order to achieve the purpose of this study; keywords, working years, fields of study, book titles of studies, publication languages of studies, source titles of studies, author information of studies, editorial information of studies, published countries, organizations made, meeting titles of studies, document type of studies and Web of Science categories of studies are examined.

\section{$2 \quad$ Method}

Content and Citation analysis was used in this study to investigate documents related to technology usage in gifted child researches, which were indexed in the Web of Science. "Technology" and "gifted" (high abilities) related keywords were used 
jointly in the search for documents. Cohen, Manion and Morrison (2007) emphasized that content analysis is a research technique consisting of arranging, classifying, comparing and extracting theoretical results from texts. In this study, content analysis has been preferred, along with aforementioned aspects, for its ability to combine similar data with certain concepts and themes and transform them into a format that the reader can understand. (Bauer, 2000; Fraenkel and Wallen, 2003; Lightning and Lightning, 2005).

As a result of the examination, firstly 240 documents are reached (4.9.2019). However, as a result of individual examination of the sources, 40 documents that are not related to the research purpose were excluded from the scope of the research. The first scan screen in the Web of Science database can be seen in Figure 1. There was a total of 200 documents judged to be relevant to the field of technology usage in gifted child education and were analyzed.

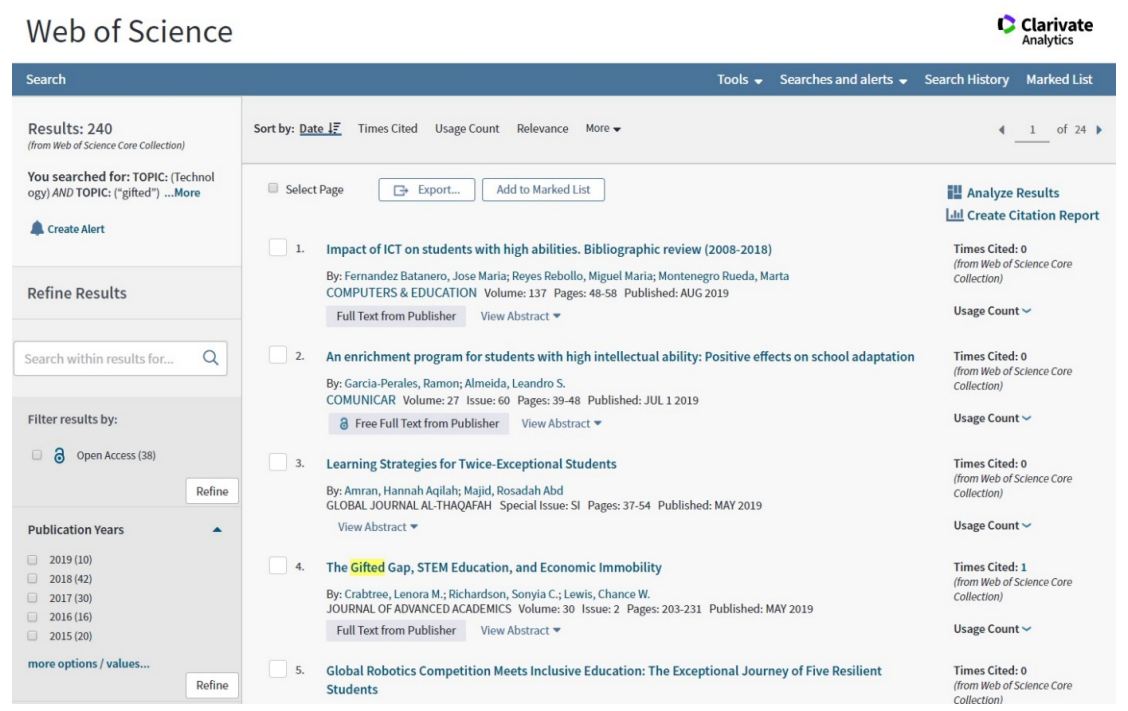

Fig. 1. Web of Science first scan result

\subsection{Analysis of data}

The frequencies of the data and the percentage ratios based on these frequencies are calculated to correspond to the answers of each research question. In the scope of research, the data obtained from the articles analyzed through content analysis are analyzed using descriptive statistical methods (percentage and frequency).

\section{Results and Discussion}

In this section, information obtained after evaluation of documents reached as a result of the scanning made in the Web of Science database are given. 


\subsection{Distribution of studies by years}

Table 1. Data related to years of studies are given in Table 1.

\begin{tabular}{|c|c|c|}
\hline Years & $\mathbf{n}$ & $\mathbf{\%}$ \\
\hline 2018 & 41 & 20.5 \\
\hline 2017 & 30 & 15 \\
\hline 2015 & 19 & 9.5 \\
\hline 2014 & 19 & 9.5 \\
\hline 2013 & 14 & 7 \\
\hline 2016 & 12 & 6 \\
\hline 2010 & 12 & 6 \\
\hline 2012 & 10 & 5 \\
\hline 2019 & 14 & 7 \\
\hline 2011 & 6 & 3 \\
\hline Others & 23 & 11.5 \\
\hline Total & $\mathbf{2 0 0}$ & $\mathbf{1 0 0}$ \\
\hline
\end{tabular}

Table 1 shows the distribution of the 200 studies obtained from the analyzes by years. When the distribution of studies related to the use of technology in gifted students by years is considered, the highest value is in $2018(\mathrm{n}=41,20.5 \%)$, and the second highest is in $2017(\mathrm{n}=30,15 \%)$. Likewise, Table 1 shows that the lowest values are listed as $2011(\mathrm{n}=6,3 \%), 2012(\mathrm{n}=10,5 \%)$ and $2010(\mathrm{n}=12,6 \%)$. In addition, 23 Publication Years value(s) are outside display options.

The main point that draws attention according to the data in Table 1 is that researches about gifted and technology have been on the rise in recent years.

\subsection{Distribution of studies by area}

Table 2. The data related to the areas of the studies are given in Table 2.

\begin{tabular}{|l|c|c|}
\hline \multicolumn{1}{|c|}{ Research Areas } & n & \% \\
\hline Education, Educational Research & 109 & 43.2 \\
\hline Psychology & 30 & 11.9 \\
\hline Engineering & 23 & 9.2 \\
\hline Computer Science & 17 & 6.7 \\
\hline Telecommunications & 8 & 3.1 \\
\hline Business, Economics & 7 & 2.7 \\
\hline Science, Technology & 7 & 2.7 \\
\hline Arts Humanities & 6 & 2.3 \\
\hline History, Philosophy of Science & 6 & 2.3 \\
\hline Chemistry & 4 & 1.5 \\
\hline Others & 38 & 15 \\
\hline Total & $\mathbf{2 5 2 *}$ & $\mathbf{1 0 0}$ \\
\hline
\end{tabular}

* Some articles are listed in more than one research area.

Table 2 shows the ranking of the 200 articles obtained from the analyzes by research fields. "Education, Educational Research" $(n=109,43.2 \%)$ has the highest 
value in the distribution of gifted students and technology-related studies by research areas and "psychology" $(\mathrm{n}=30,11.9 \%)$ has the second highest value. It is known that this ranking is an expected result, that the field of education of gifted children develops on the basis of the theoretical principles of learning and developmental psychology, and that its applications in the fields of education and educational research are guided scientifically.

Interestingly, it is seen that the third highest value is "engineering" ( $n=23,11.9 \%)$ and the fourth value is "computer science" ( $n=17,6.7 \%)$. It is seen that the changes in the field of technology have increased among the gifted students in recent years, especially intelligence games, creative applications and even coding and STEM applications are especially prominent for students. These findings are believed to be the result of these applications.

\subsection{Distribution of studies by published languages}

Table 3. The distribution of the studies by published languages is given in Table 3 .

\begin{tabular}{|l|c|c|}
\hline \multicolumn{1}{|c|}{ Languages } & N & \% \\
\hline English & 196 & 98 \\
\hline Russian & 2 & 1 \\
\hline Afrikaans & 1 & 0.5 \\
\hline Portuguese & 1 & 0.5 \\
\hline Total & $\mathbf{2 0 0}$ & $\mathbf{1 0 0}$ \\
\hline
\end{tabular}

Table 3 shows the distribution of the language of the studies about gifted children and technology by year. When Table 4 is examined, it is seen that the highest number is English ( $\mathrm{n}=196,98 \%)$, and the second highest number is Russian ( $\mathrm{n}=2,1 \%)$. Interestingly, there is also one article in Afrikaans $(n=1,0.5 \%)$ and one in Portuguese $(\mathrm{n}=1,0.5 \%)$. According to this result, it is revealed that English is the dominant language, as in other fields, in the researches about gifted and technology. 


\subsection{Distribution of studies by published sources}

Table 4. The distribution of the studies according to the publishing sources is given in Table 4.

\begin{tabular}{|l|c|c|}
\hline \multicolumn{1}{|c|}{ Sources } & n & \% \\
\hline Roeper Review a Journal on Gifted Education & 13 & 6.5 \\
\hline Gifted Child Quarterly & 9 & 4.5 \\
\hline Journal for The Education of The Gifted & 9 & 4.5 \\
\hline INTED Proceedings & 8 & 4 \\
\hline EDULEARN Proceedings & 4 & 2 \\
\hline INTED2015 9th International Technology Education and Development Conference & 4 & 2 \\
\hline Routledge Research in Achievement and Gifted Education & 4 & 2 \\
\hline $\begin{array}{l}\text { Teaching Gifted Learners in Stem Subjects Developing Talent in Science Technology } \\
\text { Engineering and Mathematics }\end{array}$ & 4 & 2 \\
\hline Theory into Practice & 4 & 2 \\
\hline High Ability Studies & 3 & 1.5 \\
\hline Others & 138 & 69 \\
\hline Toplam & $\mathbf{2 0 0}$ & $\mathbf{1 0 0}$ \\
\hline
\end{tabular}

In Table 4, the first three ranks of the published sources in which the studies about gifted and technology are; "Roeper Review a Journal" ( $n=13,6.5 \%)$ in the first place, followed by "Gifted Child Quarterly" ( $n=9,4.5 \%)$ and "Journal of the Education of The Gifted" ( $\mathrm{n}=9,4.5 \%)$ with almost same values. Referring to the values in Table 5, it can be argued that a scientific journal publishing scientific researches about "gifted education and technology" is needed.

\subsection{Distribution of studies by author information}

Table 5. The distribution of the studies by author information is given in Table 5 .

\begin{tabular}{|l|c|c|}
\hline \multicolumn{1}{|c|}{ Authors } & n & \% \\
\hline Lubinski d & 5 & 1.1 \\
\hline Benbow cp & 4 & 0.9 \\
\hline Stoeger h & 4 & 0.9 \\
\hline Wai j & 4 & 0.9 \\
\hline Baltz rh & 3 & 0.6 \\
\hline Kalemis k & 3 & 0.6 \\
\hline Olszewski-kubilius p & 3 & 0.6 \\
\hline Steenbergen-hu s & 3 & 0.6 \\
\hline Belcastro fp & 2 & 0.4 \\
\hline Cotabish a & 2 & 0.4 \\
\hline Others & 405 & 92.4 \\
\hline Total & $\mathbf{4 3 8}$ & $\mathbf{1 0 0}$ \\
\hline
\end{tabular}

Table 5 shows the distribution of findings according to the ranking of authors of the studies on gifted children and technology. Table 6 shows that LUBINSKI D $(n=5$, $1.1 \%$ ) published the most articles, followed by BENBOW CP, STOEGER $\mathrm{H}$ and WAI J with 4 articles. Referring to values in Table 6 , it can be argued that there is no 
author concentrating solely on this field, and there is a need for authors who concentrate on gifted and technology related studies.

\subsection{Distribution of authors of studies by country}

Table 6. Table 6 shows the distribution of the authors of studies by country.

\begin{tabular}{|l|c|c|}
\hline \multicolumn{1}{c|}{ Countries/Regions } & n & \% \\
\hline USA & 88 & 48 \\
\hline Peoples R China & 9 & 4.9 \\
\hline England & 8 & 4.3 \\
\hline India & 8 & 4.3 \\
\hline Germany & 6 & 3.2 \\
\hline Malaysia & 6 & 3.2 \\
\hline Spain & 6 & 3.2 \\
\hline Canada & 5 & 2.7 \\
\hline Greece & 5 & 2.7 \\
\hline South Africa & 5 & 2.7 \\
\hline Others & 36 & 19.7 \\
\hline Total & $\mathbf{1 8 2}$ & $\mathbf{1 0 0}$ \\
\hline
\end{tabular}

In Table 6, it is seen that in the distribution of authors of studies on gifted and technology by their countries USA $(n=88,48 \%)$ took the first place, China $(n=9,4.9 \%)$ took the second place, and England, India took the third place with 8 articles, followed by Germany, Malaysia and Spain with 6 sources. According to these results, it can be said that USA is dominant, as in all areas, in studies about "gifted children and technology".

\subsection{Distribution of authors by their affiliations}

Table 7. Organizational distribution of the studies is given in Table 7.

\begin{tabular}{|l|l|l|}
\hline \multicolumn{1}{|c|}{ Instructions } & n & \% \\
\hline University of North Texas & 8 & 2.2 \\
\hline Vanderbilt University & 6 & 1.6 \\
\hline Purdue University & 6 & 1.6 \\
\hline University of California System & 5 & 1.3 \\
\hline Kazan Federal University & 5 & 1.1 \\
\hline Duke University & 4 & 1.1 \\
\hline Northwestern University & 4 & 1.1 \\
\hline State University System of Florida & 4 & 1.1 \\
\hline Universiti Kebangsaan Malaysia & 4 & 0.8 \\
\hline $\begin{array}{l}\text { Cognogen Biotechnology Consult- } \\
\text { ing }\end{array}$ & 3 & 86 \\
\hline Others & 310 & $\mathbf{1 0 0}$ \\
\hline Toplam & $\mathbf{3 5 9}$ & \\
\hline
\end{tabular}

Table 7 shows the distribution of organizations related to the use of technology by gifted students. Considering this information, the universities with the highest value 
were University of North Texas $(n=8,2.2 \%)$, Vanderbilt University $(n=6,1.6 \%)$ and Purdue University $(\mathrm{n}=6,1.6 \%)$ followed by the University of California System $(\mathrm{n}=$ $5,1.3 \%)$ and Cognogen Biotechnology Consulting has the lowest data $(n=3,0.8 \%)$.

\subsection{Distribution of studies by document types}

Table 8. The distribution of the studies by document types is given in Table 8 .

\begin{tabular}{|l|c|c|}
\hline \multicolumn{1}{|c|}{ Document Types } & n & \% \\
\hline Article & 110 & 55 \\
\hline Proceedings Paper & 63 & 31.5 \\
\hline Book ChapteR & 11 & 5.5 \\
\hline Review & 7 & 3.5 \\
\hline Editorial Material & 5 & 2.5 \\
\hline Biographical Item & 1 & 0.5 \\
\hline Book & 1 & 0.5 \\
\hline Book Review & 1 & 0.5 \\
\hline Meeting Abstract & 1 & 0.5 \\
\hline Total & $\mathbf{2 0 0}$ & $\mathbf{1 0 0}$ \\
\hline
\end{tabular}

Table 8 shows the documents types related to the use of technology by gifted students. Considering this information, document type with highest number is "article" $(\mathrm{n}=110,55 \%)$, followed by the "proceedings paper" $(\mathrm{n}=63,31.5 \%)$ and "Book Chapter" $(\mathrm{n}=11,5.5 \%)$. It is noteworthy that the "Proceedings paper" document type is approximately one third of the total document type. As it is known, the development of a field starts with the presentation of the products in that field as conferences. Those who work in that field present their research and attract the attention of the audience and open the subject for discussion.

\section{$4 \quad$ Discussion and Conclusion}

In the findings of the distribution of studies about the use of technology related to gifted students by years, it was concluded that the highest value is in 2018. It was concluded that 6 studies were conducted in 2011. Kardeş, Akman \& Yazıcı (2018), found that research on the use of technology in gifted students has increased in recent years. This finding of the study supports other studies.

In the findings of the distribution of the studies about the use of technology related to gifted students by fields, it was concluded that the most researches were conducted in the field of education and the least number of studies were conducted in the field of chemistry. According to these findings, it is concluded that technology-related studies of gifted students should increase in other fields besides education. In a similar study by Kardes, Akman, Yazıcı (2018), when we look at the distribution of theses written in the field of gifted students by fields, it is seen that these are generally concentrated under the title of education and training. Theses in the field of education are originated from science branches like Department of Educational Sciences, Education Man- 
agement and Supervision, Education and Inspection, Education Programs and Teaching. Theses in the field of Special Education and psychology take the first place in the studies conducted in this field. This result is consistent with this research.

In the findings of the distribution of studies about use of technology related to gifted students by publication languages, it is seen that the researches were mostly written in English and the second highest ranking is Russian. In addition to that, it is interesting to conclude that there are articles in Afrikaans and Portuguese. According to this result, it is revealed that English is the dominant language, as in other fields, in the researches on gifted children and technology.

First three ranks in the distribution of studies about use of technology related to gifted students are: "Roeper Review a Journal on Gifted Education" at first place and followed by "Gifted Child Quarterly" and "Journal for the Education of The Gifted" with almost same values.

First three ranks in the distribution of studies about use of technology related to gifted students are: LUBINSKI D published the most articles and BENBOW CP, STOEGER $H$ and WAI $J$ are ranked with 4 articles. Based on this result, it can be argued that there is a need for authors who concentrate on gifted students and technology-related studies (Dönmez \& İdin, 2017; Cırık, 2016).

In the distrubution of the authors of the studies about use of technology related to gifted students by country It is seen that USA is in the first place, China is in the second place and England and India in the third place with 8 articles and then Germany, Malaysia and Spain come with 6 articles. According to these results, it can be argued that USA is dominant, as in all fields, in studies related to "gifted children and technology". Collins, Hall, \& Taylor (2015), Sprague \& Shaklee (2015) underlined the importance given to the concept of superior intelligence and technology by USA in their studies.

University of North Texas and Vanderbilt University have the highest value in the organizational distribution of the studies related to the use of technology related to gifted students, while the University of California ranked behind them. It was concluded that Cognogen Biotechnology Consulting was the lowest data.

In the distribution of studies about use of technology related to gifted students by document type, "article" has the highest value, followed by "proceedings paper" and thirdly "Book Chapter" document type. It is noteworthy that "Proceedings paper" document type is approximately one third of the total document type. When similar studies on the use of giftedness and technology were examined, a similar result was obtained (Cao, Jung, \& Lee 2017; Manca \& Ranieri 2016). This result can be explained by the fact that the studies conducted with the concepts of superior intelligence and technology are very few. As the field is new, it is requested to improve the researches by presenting conference notifications.

\section{$5 \quad$ Suggestions}

Gifted individuals have made great contributions to human history with their capacities and different perspectives. With respect to social, educational, scientific and 
technological fields, the share of gifted individuals can't be ignored in the rise and development of societies. Gifted individuals have not been understood throughout history because they differ from normal in many areas. In fact, from time to time, these talented individuals are believed to be problematic. As a result, weekend science feasts with immersive experiments, researches and presentations can be organized in the form of technology and games for gifted students. When the literature is reviewed, addressing all these mentioned issues by carrying out more studies within the scope of gifted children and technology would contribute to the literature is among the suggestions of this research.

In addition, for the gifted and talented children, environments that require highlevel learning skills including social media and new learning technologies should be created. These environments should include features that increase the motivation of gifted students.

\section{References}

[1] Anne T. O., Krista, D. G., Timothy, J. N., \& Peggy, A. E. (2010). Teacher Value Beliefs Associated with Using Technology: Addressing Professional and Student Needs. Computers \& Education, 55, 1321-1335.https://doi.org/10.1016/j.compedu.2010.06.002

[2] Aruk, İ. (2008). Bilişim Teknolojilerinin Zihinsel Engellilerin E-Eğitiminde Kullanılması ve Örnek Bir Ugulava Geliştirilmesi [Using Information Technologies in E-Education of Mentally Handicapped and Developing a Sample Application] Master Thesis, Trakya University

[3] Bauer, M. W. (2000). Classical content analysis: A review. Qualitative researching with text, image and sound, 131-151.https://doi.org/10.4135/9781849209731.n8

[4] Bracken reed, D. (2008). Assistive technology as an Accommodation for a Student with Mild Disabilities: The Case of Alex. Exceptionality Education International, 18(2), 69-81.

[5] Camci-Erdoğan, S. (2013). Üstün zekâlı ve yetenekli öğrencilerin bilim insanlarına yönelik alg1lar1. [Perceptions of gifted and talented students towards scientists]. Turkish Journal of Giftedness and Education, 3(1), 13-37.http://www.tuzed.org/publications/cilt3/ sayi1/2013 3 1 camcierdogan.pdf

[6] Cao, T. H., Jung, J. Y., \& Lee, J. (2017). Assessment in gifted education: A review of the literature from 2005 to 2016. Journal of Advanced Academics, 28(3), 163-203. https://doi.org/10.1177/1932202X17714572

[7] Celik Kayapinar, F., \& Savas, B. (2019). Determining elementary teacher candidates' cognitive structure on the concept of 'disabled people' through the drawing technique. New Trends and Issues Proceedings on Humanities and Social Sciences, 6(1), 78-84. https://doi.org/10.18844/prosoc.v6i1.4157

[8] Cirik, M. (2016). Uzaktan eğitimin üstün zekalı öğrencilerin eğitimindeki yeri. [The place of distance education in the education of gifted students]. Açıkögretim Uygulamalar ve Araştırmaları Dergisi, 2(3), 170-187.

[9] Cohen, L., Manion, L., \& Morrison, K. (2007). Research methods in education.

[10] Collins, G., Hall, J., \& Taylor, B. (2015). The Role of Technology in Providing Effective Gifted Education Services in Clustered Classrooms. In Cases on Instructional Technology in Gifted and Talented Education (pp. 411-435). IGI Global. https://doi.org/10.4018/ $\underline{978-1-4666-6489-0 . \operatorname{ch} 019}$ 
[11] Çatak, A. A., \& Tekinarslan, E. (2008). PowerPoint Programında Hazırlanan Okuma Materyalinin 12-13 Yaşlarında Kaynaştırma Programına Devam Eden Hafif Düzeyde Zihinsel Engelli Öğrencilerin Okuduğunu Anlama Becerisine Etkisi. [The Effect of Reading Matarial Developed in Powerpoint Software on Reading Comprehension Skll of Students Aged 12-13 Years with Mild Mental Retardation in Inclusion Programs]. Abant İzet Baysal Üniversitesi Eğitim Faculties Dergisi, 8(2), 107-124.

[12] Dönmez, İ., \& İdin, Ş. (2017). Türkiye'de fen bilimleri eğitimi alanında üstün yetenekli öğrencilerin eğitimi ile ilgili araştırmaların incelenmesi. [Turkey in the field of science education examining research on the education of gifted students]. Üstün Zekâlılar Eğitimi ve Yaratıcıllk Dergisi, 4(2), 57-74.

[13] Fraenkel, J. R., \& Wallen, N. E. (2003). How to design and evaluate research in education. McGraw-Hill Higher Education.

[14] Hırça, N., \& Bayrak, N. (2013). Sanal fizik laboratory ile üstün yeteneklilerin eğitimi: Kaldırma kuvveti konusu. [Training of the gifted with the virtual physics laboratory: Lifting force.]. Journal for the Education of Gifted Young Scientists,1(1), 16-20. https://doi.org/10.17478/JEYSG.201318999

[15] Johnsen, S. K. (2012). NAGC Pre-K-Grade 12 Gifted Education Programming Standards: A Guide to Planning and Implementing High-Quality Services. Prufrock Press Inc. PO Box 8813, Waco, TX 76714.

[16] Kardes, S., Akman, B., \& Yazıcı, D. N. (2018). Üstün Yetenekliler Alanında Yapılmış Tezlerin Analizi. [Analysis of Thesis in the Field of Gifted Students]. Journal of Theoretical Educational Sciences, 11(3), 411-430. https://doi.org/10.30831/akukeg.353279

[17] Keser, S., \& Erdem, P. (2019). The Effectiveness of Plastic Arts Education Weighted Creative Drama in The Education of Gifted / Talented Children. Contemporary Educational Research Journal, 9(1), 32-37. https://doi.org/10.18844/cerj.v9i1.3856

[18] Kurt, A. A., \& Goksun, D. (2016). Technology use via students with hearing impairment: Hear your voice and be heard. Journal of Education and Special Education Technology, 2(1), 1-12. https://doi.org/10.18844/jeset.v2i1.3887

[19] Kurtdede Fidan, N. (2008). İlköğretimde araç gereç kullanımına ilişkin öğretmen görüşleri. [Teachers' opinions about the use of equipment in primary education] Kuramsal Eğitimbilim Dergisi, 1(1), 48-61.

[20] Manca, S., \& Ranieri, M. (2016). Is Facebook still a suitable technology-enhanced learning environment? An updated critical review of the literature from 2012 to 2015. Journal of Computer Assisted Learning, 32(6), 503-528. https://doi.org/10.1111/jcal.12154

[21] Özenç, M. \& Özenç, E. G. (2013). Türkiye'de üstün yetenekli öğrencilerle ilgili yapılan lisansüstü eğitim tezlerinin çok boyutlu olarak incelenmesi. [Multidimensional examination of post-graduate theses on gifted students in Turkey]. Turkish Journal of Social Research, 171, 13-28.

[22] Özgüç, C.S., \& Cavkaytar, A. (2014). Teacher use of İnstructional technology in A Special education school for students with intellectual disabilities: A Casestudy. Turkish Online Journal of Qualitative in Quiry, 5(1), 47-59. https://doi.org/10.17569/tojqi.14394

[23] Rotter, K. (2006). Creatingin structional materials for all pupils: Try COLA. Intervention in School and Clinic, 41(5), 273-282.https://doi.org/10.1177/105345 12060410050401

[24] Sahmurov, A., Aylak, U., Bedirhanbeyoglu, H., \& Gulen, I. (2017). Examination of the Relationship between Giftedness and ADHD Symptoms during Educational Processes. New Trends and Issues Proceedings on Humanities and Social Sciences, 4(7), 52-57. https://doi.org/10.18844/prosoc.v4i3.2631 
[25] Sak, U. (2017). Anadolu-Sak zekâ olcegi. [Anadolu-Sak scale of intelligence]. 23.8.2019. Retrived from: https://www.projeiq.com/

[26] Sancar, I., Tozkoparan, S., \& Odabasi, H. (2017). Use of mobile technologies in special education: A content analysis. Journal of Education and Special Education Technology, 3(1), 1-12. https://doi.org/10.18844/jeset.v3i1.3890

[27] Seferoglu, S. S. (2006). Ögretim teknolojileri ve materyal tasarımı [Teaching technologies and material design.] Pegem A Yayıncılık.

[28] Sprague, D. R., \& Shaklee, B. (2015). Differentiating through Technology for Gifted Students. In Cases on Instructional Technology in Gifted and Talented Education (pp. 269286). IGI Global. https://doi.org/10.4018/978-1-4666-6489-0.ch013

[29] AzSubasioglu, F. (2008). Üniversitelerin Bilgi ve Belge Yönetimi Bölümleri’nin "engellilik farkındalığı" üzerine bir araştırma. [A Research on "Disability Awareness" in Information and Records Management Departments of Universities]. Bilgi Dünyası, 9(2), 399430.

[30] Uma Chandran, K., Corte, V., Amuthalakshmi, P., James, D., Said, M. M., Sawicka, B., Gaudio, G., Mohan, T., Refugio, C., Aravind, V., \& Jurcic, I. (2019). Designing learningskills towards industry 4.0. World Journal on Educational Technology: Current Issues, 11(2), 12-23. https://doi.org/10.18844/wjet.v11i2.4147

[31] Umar, Ç. N., \& Reis, Z. A. (2014). Karma öğrenme yöntemi ile farklılaştırılmış öğretim ortamının üstün zekâlı ve yetenekli öğrencilerin akademik başarılarına etkisi. [The Effects of Differentiated Curriculum with Blended Learning Method On Gifted Students' Academic Achievement]. IZÜ Sosyal Bilimler Dergisi, 3(5), 1-30.

[32] Wembler, A. (2010). The Apple iPadandtheera of ubiquitous computing [web log message]. Download from: http://andrewembler.com/apple/the-appleipad-and-the-eraof-ubiquitous-computing.

[33] Yıldırım, A. ve Şimşek, H. (2005). Sosyal bilimlerde nitel araştırma yöntemleri. [Qualitative research methods in the social sciences.]. Ankara: Seçkin Yayıncılık.

[34] [34] Yildiz, E., Alkan, A., \& Cengel, M. (2019). Teacher candidates' attitudes towards the stem and sub-dimensions of stem. Cypriot Journal of Educational Sciences, 14(2), 322344. https://doi.org/10.4018/978-1-4666-6489-0.ch013

[35] Yildiz, S. (2010). Bilgi ve İletişim Teknolojileri Yoluyla Özürlüler İçin Geleceğe Bir Kap1 Açmak. [Opening a Gateway to Future for Disabled People through Information and Communication Technologies]. Journal of International Social Research, 3(11).

[36] Yilmaz, M. (2007). Sınıf öğretmeni yetiştirmede teknoloji eğitimi [Instructional technology in training primary school teacher.]. Gazi Üniversitesi Gazi Eğitim Fakültesi Dergisi, 27(1), 155-167.

[37] Baglama, B., Haksiz, M., \& Uzunboylu, H. (2018). Technologies Used in Education of Hearing-Impaired Individuals. International Journal of Emerging Technologies in Learning (iJET), 13(09), 53-63. https://doi.org/10.3991/ijet.v13i09.8303

[38] Shubina, I., \& Kulakli, A. (2019). Pervasive Learning and Technology Usage for Creativity Development in Education. International Journal of Emerging Technologies in Learning, 14(1). https://doi.org/10.3991/ijet.v14i01.9067

\section{$7 \quad$ Authors}

Huseyin Uzunboylu graduated from Anadolu University, completing a degree in BSc Educational Communicating and Planning in 1991. He graduated from Ankara 
University; completed a degree in MA Curriculum and Instruction in 1995 and completed PhD in area of Educational Technology in 2002. He became Assistant Professor in 2013, Associate Professor in 2015 and Professor of Educational Technology in 2010 at Cyprus Near East University. Email id: huseyin.uzunboylu@gmail.com

Zehra Özçınar graduated from Küçük Kaymaklı Teacher Training College, completing a degree in BSc Primary School Teacher in 1991. She graduated from Ankara University; completed a degree in MA Curriculum and Instruction in 1995 and completed PhD in area of Educational Technology in 2003. She is Associate Professor of Educational Technology area in 2012 at Ataturk Teacher Training Academy in North Cyprus. Email id: zehra.ozcinar@aoa.edu.tr

Sergey M. Kolotushkin is a Doctor of Law, Professor, Chief Researcher of the Center of Studying of Problems of Management and the Organization Executions of Punishments in Criminally Executive System at the Federal Penal Administration Service Research Institute (14 Zhitnaya Street, GSP-1, 119991, Moscow, Russia). He is very well known in Russia with his scientific works dedicated to the different problems of punishments in criminally executive system. E-mail id: kolotushkinsm@, mail.ru

Olga A. Kalugina is Associate Professor of the Department of Foreign Languages at Financial University under the Government of the Russian Federation (49 Leningradsky prospect, 125993, Moscow, Russia). Her research interests are related to the methodology of scientific papers, education, language and linguistics. E-mail id: kaluginaruc@mail.ru

Teymur E. Zulfugarzade is $\mathrm{PhD}$ in Law, Associate Professor of the Academic Department of Civil Law at Plekhanov Russian University of Economics (36 Stremyannyi Pereulok, 115093, Moscow, Russia). He is well known in Russia as a scientist in the sphere of civil law. His research interests are also connected with law education and scientific methodology. E-mail id: teymurz@yandex.ru

Article submitted 2019-09-24. Resubmitted 2019-10-24. Final acceptance 2019-10-25. Final version published as submitted by the authors. 